\title{
O Efeito Espuma
}

\author{
Bastos F. ${ }^{1}$, Pinotti M. ${ }^{1}$ \\ ${ }^{1}$ Belo Horizonte - Brasil. \\ E-mail: drfrbastos@hotmail.com; \\ marcospinotti@me.com
}

Bastos, F.; Pinotti, M. 2013. O Efeito Espuma, p.48. In: Bastos, Francisco Reis. Anais do V Simpósio Internacional de Flebologia [Blucher Medical Proceedings n.1 v.1]. São Paulo: Blucher, 2014 http://dx.doi.org/10.5151/medpro-flebo-SIF_27
Nosso objetivo é esclarecer os fenômenos físicos que ocorrem durante a aplicação da espuma no interior das veias. Antes de mais nada é necessário entender que espuma é um conjunto de bolhas que foram formadas a partir de um filme fino. Estas bolhas possuem parede fina (alguns décimos de mícron) e contêm gás. A principal característica destas bolhas é que se podem prever suas dimensões utilizando-se conceitos matemáticos de minimização de superfícies, conhecida desde 1871 pelo matemático H. A. Schwarz. Quando estas bolhas se agrupam, para formar a espuma, também é possível modelar sua interface e se prever a sua configuração. Em bolhas de diferentes dimensões que se fundiram, pode-se observar que, uma vez que a bolha menor irá possuir sempre maior pressão que a bolha maior, a interface entre elas é uma superfície convexa, onde a pressão da bolha de menor diâmetro empurra a interface na direção do centro da bolha de maior diâmetro. Na gastronomia, o uso de bolhas e de espuma compõe os segredos e as boas práticas da culinária. Sabe-se, há muito tempo, que se pode explorar a sensibilidade das papilas gustativas ao gás carbônico para potencializar o sabor de bebidas adicionando-se pequenas bolhas de $\mathrm{CO} 2$.

A lógica da escleroterapia venosa é eliminar o refluxo do sangue através de veias de pequeno e médio calibre para favorecer o processo de drenagem do sangue. A oclusão da veia doente ocorre em decorrência da lesão química provocada por substâncias que causam irritação e destruição das células epiteliais (túnica íntima) e, ao entrar em contato com as camadas de musculatura lisa (túnica média) da veia, provoca reação de edema e contração das miofibrilas musculares. Como reação imediata, o espasmo decorrente desta lesão é responsável por mais de 50\% da redução da área da seção transversal da veia no trecho que houve contato com a substância esclerosante. O efeito tardio deste tratamento é a fibrose que ocorrerá no local da lesão química. A lógica do emprego da espuma é brilhante pelos seguintes motivos:

- permite a introdução de um volume menor de esclerosante sem, no entanto, diminuir o efeito desejado de causar lesão no epitélio;

- a veia, ao contrair, expulsa uma fração mínima de esclerosante devido a sua baixa densidade;

- o volume de esclerosante é baixo e a maior porcentagem dele é sequestrada pela veia (estudos mostram que até $94 \%$ pode ser sequestrado localmente);

- o tempo de meia vida das bolhas que formam a espuma é baixa (minutos), diminuindo riscos. 
Desta forma, ao se aplicar espuma esclerosante no interior da veia com a finalidade de provocar uma lesão química, este processo será mais eficiente quanto menores forem as bolhas da espuma. Por este motivo, o processo de geração de bolhas e a sua configuração final de microespuma, apresentam resultados superiores. Quanto menor as bolhas, maior será a área de contato entre a espuma (esclerosante) e as células epiteliais: o efeito espuma. Desta forma, a reação será mais eficiente e mais rápida.

Palavaras-chave: Efeito espuma, escleroterapia com espuma, tratamento de varizes. 